\title{
Study of outcome of pregnancy in women with heart disease
}

\author{
Hanslata Gehlot*, Nidhi Singh \\ Department of Obstetrics and Gynecology, Dr. S. N. Medical College, Jodhpur, Rajasthan, India
}

Received: 25 November 2017

Revised: 21 January 2018

Accepted: 24 January 2018

\section{*Correspondence:}

Dr. Hanslata Gehlot,

E-mail: pummyia@gmail.com

Copyright: () the author(s), publisher and licensee Medip Academy. This is an open-access article distributed under the terms of the Creative Commons Attribution Non-Commercial License, which permits unrestricted non-commercial use, distribution, and reproduction in any medium, provided the original work is properly cited.

\begin{abstract}
Background: Heart disease complicates $1 \%$ of all pregnancies. Objective of the study is to evaluate the maternal and fetal outcome in patients with cardiac disease in pregnancy.

Methods: An observational study was carried out in 25 pregnant women with known or newly diagnosed heart disease at tertiary care hospital.

Results: The average age of women was $21-25$ (36\%), in which primigravida $52 \%$ and $48 \%$ were multigravida. $56 \%$ patients were unbooked and $44 \%$ booked. Rheumatic heart disease was the commonest aetiology and was found in $56 \%$ of patients. While $16 \%$ patients had RHD with PAH. Three (12\%) patient had prosthetic valve replacement. $8 \%$ patient had Congenital heart disease while $8 \%$ had peripartum cardiomyopathy. $60 \%$ delivered vaginally and $40 \%$ of them had delivered by LSCS for various obstetrical indications. In our study none of the patient required therapeutic termination of pregnancy. Majority of patients $92 \%$ in our study group had no obstetric maternal complications. Two (8\%) maternal mortality occurred in our study. Low birth weight babies were $24 \%$, preterm labour in $4 \%$ patient. $8 \%$ babies were growth restricted. Regarding fetal outcome 25 were live birth babies. None of the patient had congenitally malformed baby and there was no perinatal loss in this study.

Conclusions: Early diagnosis of heart disease, regular antenatal checkups, institutional delivery and collaboration between cardiologist and obstetrician should result in a fall in maternal deaths from conditions already diagnosed before pregnancy.
\end{abstract}

Keywords: Cardiac disease, Maternal deaths, Pregnancy, Rheumatic heart disease

\section{INTRODUCTION}

Cardiac disease is an important cause of maternal mortality and morbidity, both in the antepartum and postpartum period. At present cardiac disease complicates $0.2-0.4 \%$ of all pregnancies in western countries. ${ }^{1}$ In developing countries like India, cardiac diseases complicate $2 \%$ of pregnancies and contribute to about one- fifth of all maternal deaths. ${ }^{2}$ In the western world, the incidence of cardiac disease during pregnancy has remained stable for many years since the significant decrease in the occurrence of rheumatic heart disease in last $40 \mathrm{yrs}$ is being compensated by an increase of pregnancy in women with congenital heart disease. Congenital heart disease is the most frequent cardiovascular disease present during pregnancy (75$82 \%$ ) in the industrialized world, with shunt lesions being predominant (20-65\%). ${ }^{3}$ Rheumatic valvular heart disease is most common cause in developing countries, comprising $56-89 \%$ of all cardiovascular diseases in pregnancy. ${ }^{2,3}$ Cardiomyopathy is uncommon, but represents severe cause of cardiovascular complications in pregnancy. Peripartum cardiomyopathy is the most frequent cause of severe complications. ${ }^{4}$ Maternal heart 
disease is now the major cause of maternal deaths during pregnancy. ${ }^{5}$

Cardiac disease during pregnancy is a challenge to obstetrician as common clinical features of cardiac lesion like breathlessness, pedal edema and murmur mimic normal pregnancy posing a diagnostic difficulty. Cardiac output increases by $30-50 \%$ during pregnancy and further increase during labour and delivery imposes a burden on diseased heart leading to complications and death. ${ }^{6-9}$ The marked pregnancy induced anatomical and functional changes in cardiac physiology can have a profound effect on underlying heart disease. Women with underlying cardiac disease may not always accommodate these changes, and ventricular dysfunction leads to cardiogenic heart failure. In most, however, heart failure develops peripartum when labor, delivery, and a number of common obstetrical conditions add undue cardiac burden. Some of these include preeclampsia, haemorrhage and anemia and sepsis syndrome.

In developing countries, the survival of newborns affected by congenital heart disease is about $85 \%$, in many cases as a result of complex surgical procedures performed in the first few months of birth. As a consequence, cardiologists and obstetricians are now facing an increasingly large group of pregnant women with surgically corrected congenital abnormalities.

Development of obstetric complications like anaemia, preeclampsia, preterm labour, fetal growth restriction are commonly seen in patients with heart disease that further worsens the outcome and complicate the management. It is essential to thoroughly evaluate the patients of underlying cardiovascular disease in order to promote optimal care during pregnancy that plays a major role in outcome. The objective of the study is to evaluate the maternal and fetal outcome in patients with cardiac disease in pregnancy.

\section{METHODS}

An observational study is conducted in Department of Obstetrics and Gynecology of Dr. S.N. Medical college, Jodhpur, India. 25 Pregnant women with history of cardiac disease or newly diagnosed heart disease for the first time in pregnancy admitted to obstetric ward, were included in the study.

Cases were referred to medical specialist for confirmation of cardiac disease and to seek their opinion regarding management. Cases directly reporting to labor room were also included in the study. Detailed history in regard to cardiac lesion was asked. Detailed obstetric history was also gathered to know the effect of cardiac disease on pregnancy and vice versa.

Thorough clinical examination was done to find out the type of cardiac lesion, any signs of failure and stage of pregnancy. The case was then investigated with specific investigations to confirm the cardiac lesion and the cardiac functional status. Cases were graded as per NYHA classification of grade of heart disease. Patients were advised to have regular antenatal check-up. They were told about the importance of rest, medication and regular visits. The data were obtained from review of medical records. Baseline data recorded including age, parity, type of lesion, New York Heart Association (NYHA) functional class, maternal complications, mode of delivery and indication of caesarean section, neonatal outcome and admission to NICU were noted. Patients were discharged after 7 days with proper postnatal advice.

\section{RESULTS}

A total of 25 pregnant women with cardiac disease were included in the study.

Table 1: Age wise distribution.

\begin{tabular}{|lll|}
\hline Age & n & Percentage \\
\hline $15-20$ & 7 & 28 \\
\hline $21-25$ & 9 & 36 \\
\hline $26-30$ & 7 & 28 \\
\hline $31-35$ & 2 & 8 \\
\hline $36-40$ & 0 & 0 \\
\hline$>40$ & 0 & 0 \\
\hline
\end{tabular}

The average age of women was out of 25 women 21-25 $(36 \%)$ in which primigravida $13(52 \%)$ and $12(48 \%)$ were multigravida. Regarding antenatal care $14(56 \%)$ patients were unbooked and $11(44 \%)$ patients were booked.

Table 2: Type of booking.

\begin{tabular}{|lll|}
\hline & Number & Percentage \\
\hline Booked & 11 & 44 \\
\hline Unbooked & 14 & 56 \\
\hline
\end{tabular}

Among women with acquired heart disease, rheumatic heart disease was the commonest aetiology and was found in $14(56 \%)$ of patients. While $4(16 \%)$ patients had RHD with PAH. Three (12\%) patient had prosthetic valve replacement. Two $(8 \%)$ patient had Congenital heart disease while $2(8 \%)$ had peripartum cardiomyopathy.

Table 3: Obstetric history.

\begin{tabular}{|lll|}
\hline & Number & Percentage \\
\hline Primigravida & 13 & 52 \\
\hline Multigravida & 12 & 48 \\
\hline
\end{tabular}

Out of 25 patients 15 (60\%) delivered vaginally and 10 (40\%) of them had delivered by LSCS for various obstetrical indications. In present study none of the patient required therapeutic termination of pregnancy. 
Majority of women in study were given antibiotics prophalaxis for bacterial endocaridis.

Table 4: NYHA class.

\begin{tabular}{|lll|}
\hline & Number & Percentage \\
\hline NYHA class I & 11 & 44 \\
\hline NYHA class II & 6 & 24 \\
\hline NYHA class III & 8 & 32 \\
\hline NYHA class IV & 0 & 0 \\
\hline
\end{tabular}

Majority of $23(92 \%)$ patient in present study group had no obstetric maternal complications. Two (8\%) maternal mortality occurred in our study. In our study majority of patient $11(44 \%)$ were in NYHA class I, $6(24 \%)$ were in NYHA class II and $8(32 \%)$ were in NYHA class III.

Table 5: Type of cardiac lesion.

\begin{tabular}{|lll|}
\hline Rheumatic heart disease & Number & Percentage \\
\hline Prosthetic valve replacement & 3 & 56 \\
\hline Peripartum cardiomyopathy & 2 & 12 \\
\hline Congenital heart disease & 2 & 8 \\
\hline RHD with PAH & 4 & 16 \\
\hline
\end{tabular}

Table 6: Mode of delivery.

\begin{tabular}{|ll|l|}
\hline & Number & Percentage \\
\hline Vaginal delivery & 15 & 60 \\
\hline Caeserean section & 10 & 40 \\
\hline
\end{tabular}

Regarding perinatal outcome, low birth weight babies numbered $6(24 \%)$, preterm labour was seen in $1(4 \%)$ patient and had very low birth weight baby. $2(8 \%)$ babies were growth restricted.

Table 7: Maternal outcome.

\begin{tabular}{|lll|}
\hline & Number & Percentage \\
\hline Maternal mortality & 2 & 0.08 \\
\hline No maternal complications & 23 & 92 \\
\hline
\end{tabular}

Regarding fetal outcome 25 (24 babies were delivered at term between $37-42$ weeks gestation) were live birth babies. None of the patient had congenitally malformed baby and there was no perinatal loss in this study.

Table 8: Perinatal outcome.

\begin{tabular}{|lll|}
\hline & Number & Percentage \\
\hline Live births & 25 & 100 \\
\hline Baby well $(>2.5 \mathrm{~kg})$ & 21 & 84 \\
\hline Low birth weight $(<2.5 \mathrm{~kg})$ & 6 & 24 \\
\hline Very low birth weight & 1 & 4 \\
\hline IUGR & 2 & 8 \\
\hline Perinatal loss (IUD/still birth) & 0 & 0 \\
\hline Congenital anomalies & 0 & 0 \\
\hline
\end{tabular}

\section{DISCUSSION}

Maternal heart disease is one of the most important cause of maternal death. In the developing countries, rheumatic heart disease remains the major cause of maternal heart disease while in developed countries maternal congenital heart disease has become more prevalent due to improved survival of children with congenital heart disease. ${ }^{10}$

In present study rheumatic heart disease is the commonest etiology and is found in $56 \%$ of cases, which was comparable to other studies and confirms that rheumatic heart disease is still predominant in developing countries like India. In this study, the commonest age group to which the patient belonged to was 21 to 25 years. The majority of the patients $52 \%$ were primigravidae. In present study, $44 \%$ were booked and 56 $\%$ were unbooked.

Functional class has a direct bearing on both the maternal and fetal outcome. $44 \%$ of patients in this study were in NYHA class I, $24 \%$ in class II and $32 \%$ in class III, which is comparable to $55 \%$ in class-I and $20 \%$ in class III in a series by Yasmeen $\mathrm{N}$ and $22.3 \%$ in a series by Shawney, $70.9 \%$ in class I and $14.55 \%$ in class II in a study by Koregal et al and $73.42 \%$ in class I and II and $21.21 \%$ in class III in a study by Khursheed. ${ }^{11-14}$

In present study, $60 \%$ of patients were delivered vaginally as compared to $62.5 \%$ in Yasmeen N, 92\% Shawney, 86\% in Asghar F, 91.42\% Hameed, and 72.8\% by Koregal studies. ${ }^{11-13,15,16} 40 \%$ of patients were delivered by caesarean section performed for obstetric indications. Percentage of caesarean section is comparable to $35 \%$ in a study carried out by Naila Yasmeen, $27.2 \%$ in study by Koregal and $26.5 \%$ in a study carried out by Asghar F and. ${ }^{11,13,15}$

Maternal death was occurred only in $8 \%$ of cases, this is in the agreement with the result $2.5 \%$ by Yasmeen N, 2\% by Sawhney et al and $3.6 \%$ by Koregal et al. ${ }^{11-13}$ Low percentage of maternal complications in present study was due to multidisciplinary approach involving cardiologist, physician, obstetrician and anaesthetist.

Similarly, because of improved perinatal care $100 \%$ cases delivered live born in current study. In Present study intrauterine growth restriction was seen in $8 \%$ compared to $18.20 \%$ and $21 \% .^{12,16}$ The low birth rate was $24 \%$ in our series compared to $29.4 \%$ in Barbosa's study. ${ }^{17}$

Preterm labour was seen in $4 \%$ cases in present study. There was a significant difference in perinatal outcomes between NYHA class I, II, III, IV in current study. The perinatal mortality rate was nil in present study. In view of the high risk of low birth weight, preterm delivery and IUGR, antenatal fetal surveillance become mandatory and should be offered to these women with rheumatic heart disease and with other cardiac disease. 


\section{CONCLUSION}

The population of pregnant women with heart disease has changed in recent decades, cardiologists and obstetricians need to be able to manage safely the majority of women who can tolerate a pregnancy and be able to recognise those few in whom a pregnancy is very high risk. Collaboration between cardiologist and obstetrician should result in a fall in maternal deaths from conditions already diagnosed before pregnancy.

Funding: No funding sources Conflict of interest: None declared

Ethical approval: The study was approved by the Institutional Ethics Committee

\section{REFERENCES}

1. Weiss BM, von Segesser LK, Alon E, Seifert B, Turina MI. Outcome of cardiovascular surgery and pregnancy: A systematic review of the period 19841996. Am J Obstet Gynecol. 1998:179:1643-53.

2. Stangl V, Schad J, Gossing G, Borges A, Baumann $\mathrm{G}$, Stangl K. Maternal heart disease and pregnancy outcome: A single-centre experience. Eur J Heart Fail. 2008;10:855-60.

3. Siu SC, Sermer M, Colman JM, Alvarez AN, Mercier LA, Morton BC et al. Prospective multicenter study of pregnancy outcomes in women with heart disease. Circulation. 2001;104:515-21.

4. Pearson GD, Veille JC, Rahimtoola S, Hsia J, Oakley CM, Hosenpud JD et al. Peripartum cardiomyopathy: National Heart, Lung and Blood Institute and Office of rare diseases (National Institutes of Health) workshop recommendations and review. JAMA. 2000;283:1183-8.

5. CEMACH. CEMACH saving mothers' Lives: Reviewing Maternal Deaths to Make Motherhood Safer-2003-2005: The Seventh Report on Confidential Enquiries into Maternal Deaths in United Kingdom. Centre for Maternal and Child Enquiries, London;2008.

6. Cunninghum FG, Leveno KJ, Bloom SL, Hauth JC, Rouse DJ, Spong CY, editors. Cardiovascular Diseases In Williams Obstetrics. 24 $4^{\text {th }}$ ed. Mcgraw Hill Educations; New York;2010.
7. James DK, Steer PJ, Weiner CP, Gonik B. High risk pregnancy management option. In cardiac disease in pregnancy. 4th ed. 2012;627-56.

8. Bhatla, Yadav, Mishra. The cardiac case. In Ian Donald's practical obstetrics problems. $6^{\text {th }} \mathrm{ed}$. BI Publication Pvt Ltd. India. 2010;103-26.

9. Davies GA, Herbert WN. Assessment and management of cardiac disease in pregnancy. Int Obstet Gynaecol. 2007;29(24):331-6.

10. Devabhaktuni P, Dev'neni K, Vemuri UR, Naman GV. Pregnancy outcome in chronic rheumatic heart disease. J obstet Gynaecol India. 2009;59(1):41-6.

11. Yasmeen NA, Aleem MA, Iqbal NA. Fetomaternal out come in patients with cardiac disease in pregnancy. Pak J Med Health Sci. 2011 Oct;5(4):748-51.

12. Sawhney H, Aggarwal N, Suri V, Vasishta K, Sharma Y, Grover A. Maternal and perinatal outcome in rheumatic heart disease. Int J Gynecol Obstet. 2003 Jan 1;80(1):9-14.

13. Koregol M, Mahale N, Nayak R, Bhandary A. Maternal and perinatal outcomes of pregnancies complicated by cardiac disease. J Turkish German Gynaecol Assoc. 2009;10:30-4.

14. Khursheed R, Tabasum A, Zargar B. Maternal and Fetal outcome in pregnancies complicated with maternal cardiac diseases: Experience at a Tertiary Care Hospital. Internet $\mathbf{J}$ Gynaecol Obstet. 2015;19(1):1-6.

15. Asghar F, Kokab H. Evaluation and outcome of pregnancy complicated by heart disease. J Pak Med Assoc. 2005;19:1-2.

16. Hameed A, Karaalp IS, Tummala PP, Wani OR, Canetti M, Akhter MW, et al. The effect of valvular disease on maternal and fetal outcome of pregnancy. J Am Coll Cardiol. 2001 Mar;37(3):893-9.

17. Barbosa PJ, Lopes AA, Feitosa GS, Almeida RV, Silva RM, Brito JC et al. Prognostic factors of rheumatic mitral stenosis during pregnancy and puerperium. Arg Brass Cardiol. 2000;75:215-24.

Cite this article as: Gehlot $\mathrm{H}$, Singh N. Study of outcome of pregnancy in women with heart disease. Int J Reprod Contracept Obstet Gynecol 2018;7:91720. 